\title{
O USO DO CORPO COMO FERRAMENTA PEDAGÓGICA: UM MODELO ALTERNATIVO QUE DESCONSIDERA A AUSÊNCIA DE RECURSOS ESPECÍFICOS PARA $O$ ENSINO DE BIOQUÍMICA E BIOLOGIA MOLECULAR NO ENSINO FUNDAMENTAL
}

Leandro Marcio Moreira

Biólogo formado pela Universidade São Judas Tadeu. Mestre e Doutor em Bioquímica pelo Instituto de Química da Universidade de São Paulo. Pós-doutorando em Biologia Molecular pelo Instituto de Biociências da Universidade de São Paulo. Professor de Biologia e disciplinas afins nos ensinos fundamental, médio e superior.

\section{Resumo:}

Com muita freqüência, conceitos científicos sofrem alterações por intermédio de novas descobertas, mas pouco deste novo conhecimento é repassado aos alunos, principalmente àqueles que compõem o Ensino Fundamental II (EF-II) e o Ensino Médio (EM), pois a complexidade das informações geradas dificulta esta abordagem. Entretanto, dia após dia se fala cada vez mais em assuntos que mexem com a curiosidade das pessoas, como é o caso do DNA e do metabolismo, geralmente relacionando tais assuntos com doenças emergentes como câncer, diabetes, Alzheimer, entre outras. Se o assunto é tão comentado assim nos meios de comunicação, por que não dar uma ênfase mais técnica a respeito destes tópicos em sala de aula, demonstrando ao aluno uma forma diferenciada de compreender conceitos, essencialmente por intermédio de atividades lúdicas. Neste trabalho são descritas duas atividades lúdico-pedagógicas que demonstram, de maneira prática, uma alternativa sobre como ensinar os processos de divisão celular mitótica e fisiologia do sistema respiratório para alunos do EF-II, envolvendo a descoberta de conceitos importantes para a compreensão dos fenômenos moleculares envolvidos com estes assuntos. Estas atividades ainda apresentam a peculiaridade de terem baixo custo de produção e fácil implementação.

\begin{abstract}
:
Frequently, scientific concepts are altered through scientific outbreaks, but little of that knowledge is passed on to students, especially those from Middle and High School, therefore the complexity of the information involved makes this approach more difficult. Nonetheless, these subject matters which awake people's curiosity are talked about more and more as times change. A good example of that are both DNA and metabolism, generally relating these to subjects involving emerging diseases such as cancer, diabetes, Alzheimer, among others. If the subject matter is so popular among means of communication, why not use a more technical approach on these topics in the classroom, showing students different ways of understanding and grasping concepts, basically though fun and playful activities. In this assignment two playful activities are described, both demonstrating, very practically, an alternative way of teaching mitotic cellular division process and physiology of the respiratory system to Middle School students, involving the discovering of important concepts to the comprehension of molecule phenomenon on the subject. Yet these activities have presented themselves as being of low production cost and easy implementation.
\end{abstract}

Colégio Petrópolis, Av. Pery Ronchetti 890, CEP 09771-000, Nova Petrópolis, São Bernardo do Campo, SP, Brasil, email: leandro.bio@colegiopetropolis.com

Departamento de Botânica, Instituto de Biociências, Universidade de São Paulo, Rua do Matão 277, Caixa Postal 11461, CEP 05422-970, São Paulo, SP, Brasil, e-mail: Immorei@gmail.com. 


\section{INTRODUÇÃO}

Após a descoberta da molécula de DNA na década de 50 [1], o conhecimento científico nas áreas de Bioquímica e Biologia Molecular deram um salto de desenvolvimento nunca antes observado. O volume de informações geradas a cada dia passou a ser tão grande que é quase impossível acompanhar as novidades com afinco e, devido à complexidade e grau de aprofundamento, apenas uma pequena fração deste conhecimento é repassado à população por intermédio de diferentes mídias, bem como formalmente aos alunos das redes escolares. Se não bastasse, este conhecimento ainda se depara com o fato de ser parte de um assunto extremamente abstrato, o que dificulta ainda mais a apreciação pelo conhecimento [2]. Portanto, facilitar a compreensão destes assuntos, assim como desenvolver metodologias que facilitem a relação ensino/aprendizagem passou a ser uma necessidade nos atuais contextos educacionais [3-5], principalmente em séries iniciais do Ensino Fundamental II (EF-II). Neste trabalho são demonstrados de maneira detalhada e por intermédio do lúdico a introdução dos conceitos que norteiam os eventos de duplicação celular e das trocas gasosas aos alunos do EF-II, tendo como referencial de estudo a composição química e o comportamento da molécula de DNA durante o processo mitótico, e da hemoglobina no interior das hemácias durante o fluxo sangüíneo, dando aprofundamento no crescente das grades curriculares e sem a necessidade da exigência de conceitos pesados e formalidade de estudo, que tradicionalmente estão envolvidos com o assunto. Para isso foram usados como ferramentas os próprios alunos, o que fez com que a metodologia se caracterizasse por apresentar baixo custo de produção com extrema facilidade de aplicação, propiciando momentos de inter-relação entre alunos, mas essencialmente entre professor e alunos.

\section{OBJETIVOS}

Desenvolver novas metodologias de abordagem que permitam introduzir conceitos bioquímicos e biomoleculares a respeito do evento de duplicação celular (mitose) e das trocas gasosas que ocorrem no corpo humano para alunos que compõem o EF-II, tendo como base de estudos o comportamento da molécula de DNA e a função da hemoglobina na oxigenação dos tecidos, respectivamente. Criar ferramentas lúdico-pedagógicas de baixo custo de produção associadas a uma ampla aplicabilidade, podendo ser extendidas ao ensino superior, guardada as respectivas adequações, sem a exigência de qualquer conceito formal a respeito do assunto.

\section{MODELOS PROPOSTOS}

\section{1) Duplicação celular (mitose) e armazenamento de informações genéticas: o DNA como mediador da hereditariedade}

\subsection{Materiais e métodos}

Para a montagem dos colares, cortar figuras geométricas utilizando cartolinas de cores diferentes. As figuras geométricas devem ser complementares no formato, ou seja, uma determinada figura deve ter encaixe perfeito com a outra, com as dimensões e formatos sugeridos na Figura 1A1. Cada um dos quatro formatos deverá ter cor diferenciada e ser nomeado de acordo com as bases nitrogenadas que formam a molécula de DNA, Adenina (A), Timina (T), Citosina (C) e Guanina (G), respectivamente. O total de figuras deve ser maior ou igual a duas vezes o número

1 Estas figuras geométricas devem apresentar formatos coesivos que se encaixam obrigatoriamente numa única combinação, de tal maneira que o A sempre se encaixa com o $\mathrm{T}$ e o G sempre se encaixa com o C. É importante ter A e G com dimensões maiores que $T$ e $C$, justificando o tamanho das purinas em relação às pirimidinas, ver figura 1 . 
total de alunos, para que cada colar tenha duas figuras (pingentes), uma que ficará no peito e a outra nas costas, a fim de identificar o nucleotídeo em diferentes perspectivas (Figura 1B). Neste exato momento, é importante que o aplicador do modelo relembre um importante conceito bioquímico para o sucesso da introdução da metodologia: o número de figuras geométricas que representam as bases $G$ e $A$ (purinas) devem, obrigatoriamente, ser igual ao número de $\mathrm{C}$ e $\mathrm{T}$ (pirimidinas), respectivamente $(\mathrm{G}+\mathrm{A}=\mathrm{C}+\mathrm{T})$. Em contrapartida, não há a necessidade de se ter iguais proporções entre purinas ou pirimidinas $(G+C \neq A+T)$. Dando continuidade à preparação, fazer dois furos nos cantos superiores de cada figura geométrica, previamente nomeada com as bases nitrogenadas citadas acima. Em paralelo a isso, cortar pedaços de barbante, de aproximadamente $40 \mathrm{~cm}$ de comprimento, e amarrálos às figuras geométricas de cartolina, previamente cortadas, nomeados e furadas (Figura 1A). As figuras geométricas em cartolina serão análogas a pingentes (ventral ou dorsal) sustentados por uma corrente (o barbante) (Figura 1A).

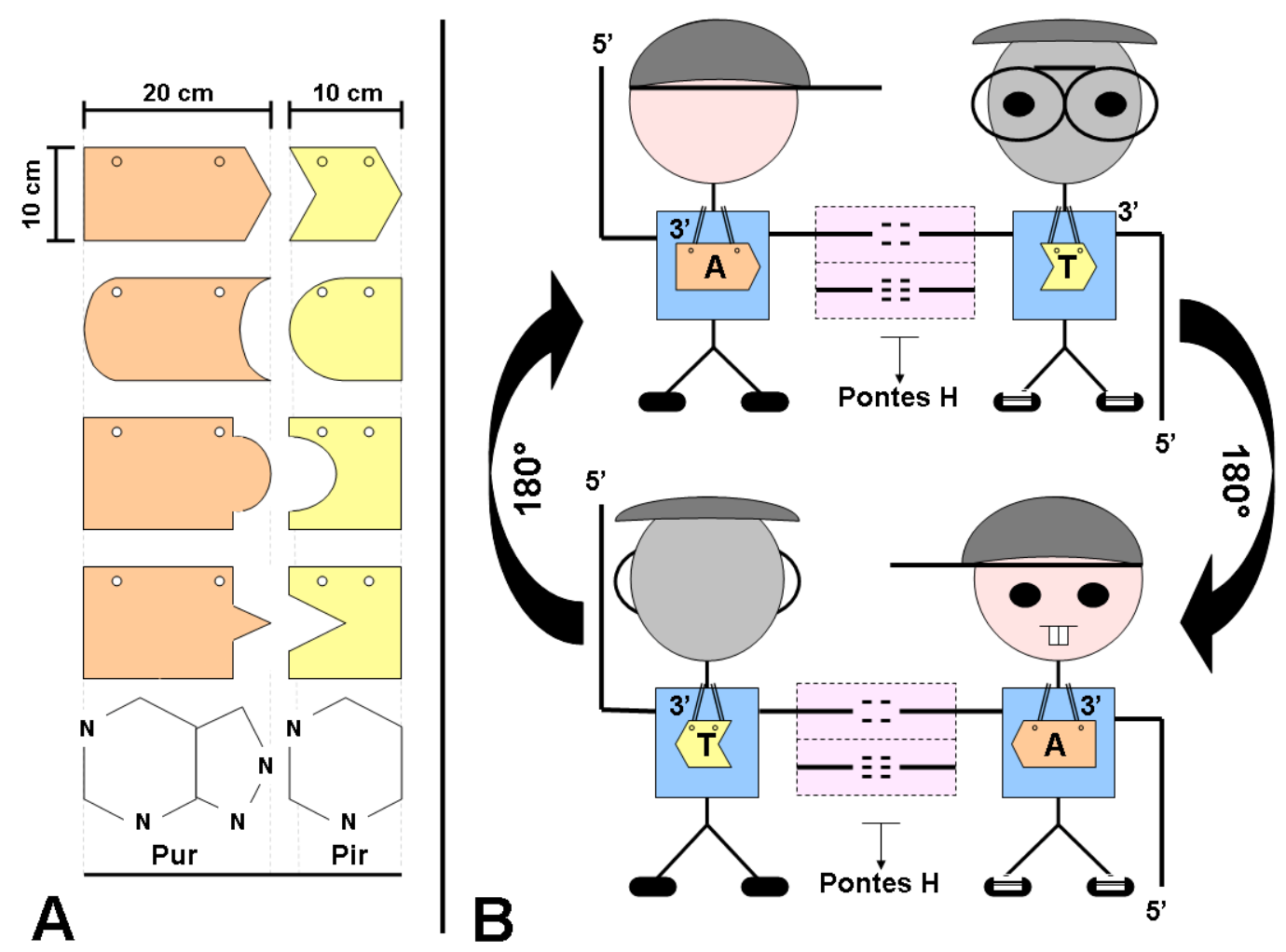

Figura 1: Modelo geral de produção dos colares e representação da paridade entre nucleotídeos complementares. (A) Esquema de quatro possíveis modelos de confecção dos colares. Observe que todas as figuras que representam as purinas (Pur) apresentam um comprimento duas vezes maior que as pirimidinas (Pir), diferença esta que reflete o real tamanho molecular das Pur em relação às Pir. As dimensões propostas são ideais para a estrutura corporal de crianças na faixa etária entre 10 e 11 anos de idade. O uso das cores diferenciadas facilita a associação de $A=T$ e $C=G$. Dois furos em cada uma das figuras devem ser feitos para permitir transpor o barbante durante a confecção do colar (ver metodologias). A adição de uma máscara de material impermeável sobre as figuras geométricas aumenta o tempo de deterioração. (B) Modelo de paridade entre dois nucleotídeos complementares representados por alunos, mantendo o anti-paralelismo e a regra de ligação dos dedos (ver metodologias). Em caso de ligações do tipo G-C três dedos seriam representados (pontes de hidrogênio), ao passo que em A-T apenas dois (linhas pontilhadas, em fundo rosa). Observe que o giro em $180^{\circ}$ não alterou a disposição das fitas e nem o sentido de ligação entre as bases nitrogenadas (colares). Isto é muito importante para promover a real compreensão do conceito. 
Distribuir os colares confeccionados aos alunos de maneira aleatória, mas nunca esquecendo de fornecer um exato número de pareamentos entre as bases que se ligam. Cada aluno com o colar no pescoço passa então a ser considerado um nucleotídeo, composto por um grupo fosfato, uma pentose e uma base nitrogenada. Neste nucleotídeo, denomina-se a posição $5^{\prime}$ do açúcar Desoxirribose (pentose) o antebraço da mão esquerda, e a mão, propriamente dita, corresponderia ao grupo fosfato, ao passo que a posição $3^{\prime}$ deste mesmo açúcar corresponde ao ombro esquerdo 2 (Figura 2 - box B). A base nitrogenada será representada pela mão direita seguindo os seguintes critérios: nas bases $G$ e $C$ três dedos devem permanecer esticados ao passo que nas bases $\mathrm{A}$ e $\mathrm{T}$ apenas dois dedos devem manter este padrão (Figura 2 - box D). Nucleotídeos que compõem a mesma fita da molécula de DNA devem se ligar pelas posições $5^{\prime} \rightarrow 3^{\prime}$, ou seja, o ombro no primeiro aluno deverá ser seguro pela mão esquerda do aluno que vem logo atrás (ou adiante levando em consideração a estruturação do DNA), o ombro do segundo deverá ser seguro pela mão esquerda do seu antecessor e assim por diante, até completar a fita (Figura 2).

As fitas devem estar posicionadas paralelamente uma à outra, porém de maneira invertida, dando o caráter de anti-paralelismo da molécula de DNA (Figura 2 - box A). Isso acarretará a obrigatoriedade das ligações A-T e G-C entre fitas opostas (Figura 2 - box D), já que a ligação é dada pela base nitrogenada, o que impede a troca da mão esquerda pela direita na montagem da fita3 (Figura 2). A união entre as fitas anti-paralelas deve seguir o padrão de ligações dos nucleotídeos, ou seja A e T devem se ligar por dois dedos, e G e C por três dedos (previamente citados), sendo que cada ligação entre os dedos representa uma ponte de hidrogênio (Figura 2 - box D). Em paralelo à formação das fitas, alguns alunos deverão representar nucleotídeos não ligados e, portanto, não farão parte da composição das fitas de DNA, em um primeiro instante. O professor ou instrutor responsável atuará com função análoga ao complexo enzimático Topoisomerase - Helicase - DNA polimerase (THP) $[6,7]$, promovendo a abertura das fitas anti-paralelas durante o evento de duplicação propriamente dito, pelo simples fato de passar entre elas, rompendo, com isso, as pontes de hidrogênio formadas pela ligação entre os dedos dos alunos (Figura 2). É importante frisar que, em caso de número ímpar de alunos, um dos alunos deverá auxiliar o professor na formação do complexo THP, já que a obrigatoriedade na paridade das bases impossibilitaria a adesão deste nucleotídeo "órfão" à fita de DNA.

No exato momento em que as fitas começarem a ser abertas, por ação do complexo THP, os nucleotídeos soltos deverão se ligar a uma base complementar das fitas já formadas, seguindo as regras de pareamento (Figura 2). É importante orientar os alunos que compõe estes nucleotídeos soltos que, a rápida ligação deles à molécula de DNA entreaberta impossibilita a re-associação das fitas originais, possibilitando, consequentemente, a geração das duas novas fitas. Ao término do processo e completa abertura das fitas de DNA, outras duas fitas estarão formadas, e esta formação é justificada pelo processo de semi-conservação das fitas do DNA (Figura 2 - box E) finalizando a primeira etapa da duplicação celular [8]. Após este processo, deve se dar continuidade ao programa de explicações a respeito da divisão celular propriamente dita, mas isto fica a critério de cada professor, desde que o mesmo, sempre que necessário, reitere a abordagem de que uma célula só se duplica se o seu material genético o fizer anteriormente $[6,7]$.

2 A nomenclatura 5' é decorrente da ligação do grupo fosfato ao carbono 5 da pentose de seu respectivo nucleotídeo $(n)$, ao passo que a nomenclatura 3' decorre da ligação do carbono 3 da mesma pentose ao grupo fosfato que compõe o pentose do nucleotídeo subseqüente $(n+1)$.

3 Como ficou estipulado que a mão direita sempre representará as bases nitrogenadas dos nucleotídeos, é impossível manter a linearidade da dupla fita da molécula de DNA estando em qualquer outra posição que não seja a dada pelo anti-paralelismo das mesmas. Isto anula a possibilidade de erros durante a dinâmica. 


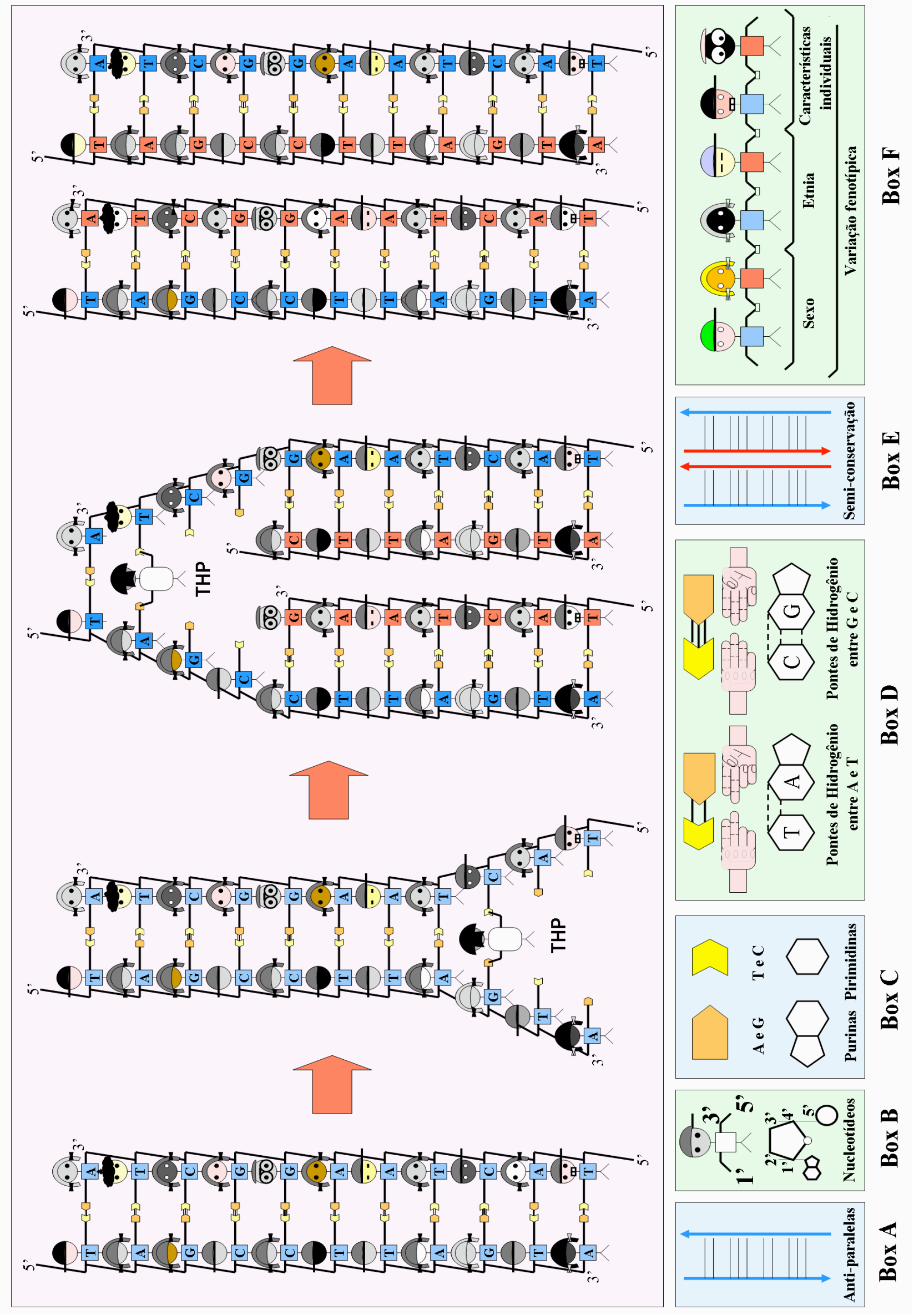


Figura 2: Modelo de duplicação da molécula de DNA composta por alunos. A molécula de DNA é formada inteiramente por crianças dispostas em fitas anti-paralelas, justificando a disposição das fitas que compõem o DNA (box A). O professor representa o complexo de proteínas THP, responsável pela abertura das fitas de DNA durante o processo de duplicação do material genético. Cada criança corresponde a um nucleotídeo, estando a base nitrogenada posicionada na mão direita, o grupo fosfato na mão esquerda e o ombro esquerdo servindo como referencial da posição 3' da Desoxirribose (box B). A ligação entre crianças que compõe uma mesma fita é dada pelo contato direto entre a mão esquerda de uma criança ( $\left.5^{\prime}\right)$ e o ombro da criança que está à sua frente ( $\left.3^{\prime}\right)$. Bases púricas, Adenina $(A)$ e Guanina $(G)$, estão representadas por pentágonos, ao passo que as bases pirimídicas, Timina ( $T$ ) e Citosina (C), estão representadas por divisas ou figuras geométricas coesivas (box C). A ligação entre as fitas deve seguir o conceito básico de pareamento dos nucleotídeos, A e T apresentam-se ligados por duas pontes de hidrogênio, ao passo que $\mathrm{G}$ e $\mathrm{C}$ apresentam-se ligados por três pontes de hidrogênio, representadas, neste caso, por dois ou três dedos da mão direita, respectivamente (box $\mathrm{D}$ ). Ao término do processo de duplicação, observa-se a formação de duas moléculas de DNA idênticas à matriz, caracterizando o fenômeno de semi-conservação do processo de duplicação (box E) [8]. O fato de darem as mãos para formarem as ligações é um estímulo para com atitudes de carinho. Além de demonstrar efetivamente como ocorre o processo de duplicação da molécula de DNA, o modelo propõe quebrar alguns paradigmas que ainda ocorrem no âmbito escolar, como por exemplo, descriminação sexual, étnica ou baseada em características individuais (box F).

\subsection{Resultados obtidos e Dificuldades iniciais de implementação}

O volume de aprendizado ou de conceitos assimilados ficou evidenciado através de participações de alunos outrora ausentes durante as aulas, indicando que a metodologia provocou efeitos positivos no interesse dos mesmos. Afirmações e questionamentos do tipo "Estas aulas práticas foram melhores que as tradicionais", "Professor queremos mais aulas assim!" ou simplesmente "Professor, amanhã tem mais?" foram reflexos de que uma mudança na metodologia das aulas se fazia necessária. A amplitude de discussão sobre os temas também foi mais elaborada do que mediante aulas expositivas, observadas previamente com outras turmas, resultado este evidenciado após processo avaliatório4 (Tabela 1).

Isto demonstrou que a discussão foi fruto de um maior interesse por parte dos alunos, e o estopim para a busca de informações em outras fontes, como jornais, revistas ou mesmo internet, com a aquisição de um montante de material praticamente impossível de ser discutido ao longo do ano letivo, reiterando o interesse pelo assunto [9]. O mais interessante é que durante as avaliações foram observadas respostas mais robustas e embasadas em conceitos tecnicamente mais elaborados, frutos do interesse pela aula e pelo assunto.

Um destaque positivo da implementação da metodologia foi o baixo custo de produção, em torno de $\mathrm{R} \$ 8,00$ ou aproximadamente $U \$ 3,00$, com a vantagem de utilizar o mesmo material em diferentes turmas de alunos, sem a necessidade da produção individual por turma. A aplicação de uma mascará impermeável (papel Contact $^{T M}$ ), sobre as cartolinas já identificadas, favoreceu uma durabilidade ainda maior aos acessórios do modelo. Demonstrando que com baixíssimo investimento é possível investir em temas científicos nas salas de aula, sem a necessidade de reagentes químicos caros ou mesmo de recursos inexistentes em muitas das escolas.

4 As avaliações constaram de questões dissertativas envolvendo conteúdos técnicos a respeito do processo exemplificado na dinâmica, em associação a temas do cotidiano envolvidos com a temática da aula (dados não mostrados). 
Tabela 1: Análise quantitativa envolvendo dados a respeito da metodologia adotada em associação com os resultados pós-avaliatórios em diferentes séries do EF-II nos anos de 2005 e 2006.

\begin{tabular}{|c|c|c|c|c|c|c|}
\hline \multirow[b]{2}{*}{ Características } & \multicolumn{6}{|c|}{ Séries do EF-II, ano de 2005} \\
\hline & $5^{\mathbf{a}}$ & $6^{a}(1)$ & $6^{a}(2) \#$ & $7^{a}(1)$ & $7^{a}(2) \#$ & $8^{a}$ \\
\hline Tempo de aula ${ }^{a}$ & 50 & 50 & 50 & 50 & 50 & 50 \\
\hline Número de aulas ${ }^{b}$ & 3 & 3 & 3 & 2 & 3 & 2 \\
\hline Total de Alunos (A) & 38 & 31 & 35 & 32 & 36 & 38 \\
\hline Questionamentos (B) ${ }^{\mathrm{c}}$ & 12 & 15 & 9 & 19 & 12 & 14 \\
\hline Relação B/A & 0,31 & 0,48 & 0,25 & 0,59 & 0,33 & 0,36 \\
\hline Conceitos satisfatórios ${ }^{d}$ & $58 \%$ & $72 \%$ & $54 \%$ & $77 \%$ & $63 \%$ & $71 \%$ \\
\hline \multirow[b]{2}{*}{ Características } & \multicolumn{6}{|c|}{ Séries do EF-II, ano de 2006} \\
\hline & $5^{\mathbf{a}}$ & $6^{a}\left(5^{a}\right)$ & $7^{a}\left(6^{a}-1\right)$ & $7^{a}\left(6^{a}-2\right)$ & $8^{a}\left(7^{a}-1\right)$ & $8^{a}\left(7^{a}-2\right)$ \\
\hline Tempo de aula ${ }^{a}$ & 50 & 50 & 50 & 50 & 50 & 50 \\
\hline Número de aulas ${ }^{b}$ & 2 & 2 & 2 & 3 & 2 & 2 \\
\hline Total de Alunos (A) & 36 & 36 & 32 & 38 & 35 & 36 \\
\hline Questionamentos (B) ${ }^{\mathrm{C}}$ & 16 & 13 & 17 & 18 & 16 & 16 \\
\hline Relação B/A & 0,44 & 0,36 & 0,53 & 0,47 & 0,45 & 0,44 \\
\hline Conceitos satisfatórios ${ }^{d}$ & $73 \%$ & $77 \%$ & $82 \%$ & $71 \%$ & $78 \%$ & $75 \%$ \\
\hline
\end{tabular}

${ }^{a}$ Tempo de aula expresso em minutos; ${ }^{\text {b }}$ Número de aulas usadas para a aplicação do conteúdo planejado, sendo uma aula por semana; "O número de questionamentos refere-se ao total de perguntas feitas pelos alunos durante o período das aulas; ${ }^{d}$ Um conceito foi considerado satisfatório, quando pelo menos $60 \%$ das perguntas apresentadas na avaliação escrita foram respondidas de maneira apreciável; Os números entre parênteses dispostos no painel superior indicam uma nomenclatura de identificação de duas séries idênticas; No caso do painel inferior a nomenclatura entre parênteses refere-se à respectiva série representada no painel superior, no ano de 2005; \# - denota salas de aula onde não foram aplicadas as metodologias aqui descritas, sendo considerada, portanto, uma sala de aula controle. Note que o percentual de conceitos satisfatórios obtidos em 2005, nas turmas controle, foi menor do que nas turmas onde as metodologias foram aplicadas, e que em 2006 a reaplicação das metodologias nas salas manteve certa homogeneidade no percentual de conceitos satisfatórios, com o fato de que as turmas que refizeram a metodologia nas série subseqüentes terem conseguido um número mais expressivos de conceitos satisfatórios.

Em cada uma das séries onde a metodologia foi aplicada, diferentes observações e curiosidades puderam ser registradas. Seguem algumas destas curiosidades e observações que notificadas durante a aplicação da metodologia:

- Nas séries iniciais do EF-II foi registrada uma maior dificuldade de coordenação dos alunos, agravada pela ausência de um auxiliar de aplicação. Na quinta série, especialmente, a hiperatividade dos alunos diante de uma atividade nova foi tanta que em alguns momentos chegou a ser difícil ganhar a atenção deles. Um agravante nesta desatenção foi decorrente da dificuldade de interação entre os alunos, muitas vezes por alguma forma de descriminação étnica, física ou mesmo de postura e vestimenta, corroborado pelo fato de haver contato físico por intermédio das mãos. Embora sejam assuntos não correlacionados com os propósitos deste trabalho, a metodologia foi capaz de, até certo ponto, anular estas diversidades, pelo simples fato de todos os alunos presentes terem a mesma função (nucleotídeos), e que a ausência de pelo menos um deles prejudicaria todo o andamento do processo. Curiosamente, a prévia anulação do contato pelas mãos, rapidamente foi esquecida pelo interesse da atividade (Figura 2 - box E).

- Ainda na quinta série, uma problemática inesperada ocorreu com os alunos que correspondiam aos nucleotídeos soltos no processo de duplicação. A terminologia "soltos", para os alunos, soou como um fator de exclusão e, interessantemente, ninguém, inicialmente, se propôs a ter esta função. Assim, é de suma importância justificar, antes de tudo, a importância destes 
nucleotídeos "soltos" (alunos) para a dinâmica da aula, ou caso contrário o docente correrá o risco de não ter uma duplicação completa do DNA por falta de material.

- A interrupção do evento, quando ocorrer, deve se proceder de forma rápida e concisa para o esclarecimento de uma dúvida posicional. Caso contrário, os alunos mais ansiosos e os superativos sairão do estado de concentração e perderão, mesmo que momentaneamente, o prazer de continuar participando do processo.

- Depois de finalizado a dinâmica, caso algum aluno ainda tenha dúvidas que se correlacionem com a percepção estrutural da molécula de DNA (dupla fita antiparalela), leve-o a olhar o modelo sob outra perspectiva. Sugere-se aqui a possibilidade deste aluno se ausentar do modelo, olhando-o de fora em diferentes posições e ângulos. Em última instância, faça-o observar a estrutura de cima para baixo, de preferência sobre algum objeto que permita esta visualização. A visão panorâmica facilitará esta apreciação.

- Ao final de todo o processo é interessante recolher dos alunos um relatório que mostre esquematicamente o que os mesmos puderam apreciar com a metodologia. Serão notadas as mais diversificadas formas de representar o mesmo modelo, com variações extremas no grau de complexidade, mas com características em comum. A grande maioria nunca se esquece da paridade de nucleotídeos (A-T e G-C), do anti-paralelismo das fitas e do processo de duplicação em si, conceitos estes básicos, mas extremamente importantes no estudo molecular da estrutura do DNA, já introduzidos de maneira robusta e bem aceita na $5^{a}$ série do EF-II.

- Em séries mais avançadas, pelo fato dos alunos se conhecerem a mais tempo, não se observa os problemas e dificuldades supra-citados em séries iniciais. Em contrapartida, o início de aplicação da atividade se mostrou dificultosa e crucial para o andamento da mesma. Inicialmente nenhum aluno, principalmente do sexo masculino, quis parear com outro de mesmo sexo, em decorrência de analogias por afinidade sexual, fenômeno típico da idade [10]. No entanto, quando pelo menos uma dupla se disponibilizou a parear, todas as outras acompanharam o processo. Daí a importância do convencimento da atividade junto a alunos considerados líderes de motivação, eles facilitaram a dinâmica de aplicação.

- Sob o ponto de vista prático, a dinâmica nas séries avançadas se procedeu em um tempo mais curto, o que proporcionou uma sobra de tempo maior dentro de um mesmo período de aula. Este ganho de tempo é fundamental para a implementação de variações metodológicas, muitas vezes decorrentes de questionamentos mais aprimorados. O tempo ganho com a dinâmica pode ser usado para introduzir o conceito de mutações, por exemplo, amplamente comentado e divulgado por intermédio de jornais, revistas e programas de TV.

- Ainda na terceira e quarta séries do EF-II (7a e $8^{a}$ séries), acrescentamos a dinâmica de síntese da molécula de RNA a partir da seqüência de DNA, um importante passo para se entender o que é e como é produzida uma proteína. Mas para isso teve que ser criado mais um nucleotídeo, a Uracila (U), da mesma maneira como foram criados os outros nucleotídeos descritos nos materiais e métodos.

\section{3 - Considerações metodológicas}

Levando em conta que o aprendizado em espiral seja uma boa alternativa de recapitulação e aprendizado gradual [11], em cada um das séries do EF-II conceitos adicionais podem ser incorporados utilizando a mesma metodologia (Figura 3 ). Os dados descritos acima são decorrentes das atividades propostas para a última série do ciclo, onde os alunos já compreendem o que é uma estruturação molecular e 
conseguem visualizar a disposição espacial de cadeias carbônicas, já que são utilizados com freqüência a nomenclatura $5^{\prime}$ e $3^{\prime}$ na síntese da molécula de DNA nas aulas de Biologia.

A Figura 3 representa um esboço da contínua agregação de conceitos usando a mesma metodologia ao longo dos anos, com base na maturação cognitiva dos alunos. Com o crescente das grades curriculares torna-se necessário a introdução de novos conceitos, que em alguns momentos acabam levando o aplicador a modificar a idéia inicial da proposta metodológica. Em decorrência destas modificações, ao qual foram deparadas em sala de aula, estão descritas a seguir, se forma sumarizada, algumas práticas que favoreceram o incremento da informação e o esclarecimento de dúvidas que surgirão no decorrer da prática da atividade, também de maneira lúdica. O conceito de mutações, por exemplo, foi abordado de várias maneiras, mas sempre mantendo o conceito de que mudanças na estruturação das moléculas de DNA acarretariam obrigatoriamente modificações nas características celulares. Assim, retirando, colocando ou simplesmente invertendo a seqüência de nucleotídeos (alunos), haveria uma modificação na seqüência do DNA, a então denominada mutação, e que estas modificações poderiam se dar por agentes químicos (brometo de etídeo), físicos (luz UV ou raios $X$ ) ou mesmo biológicos (retrovírus). Em alguns casos, a introdução a respeito da síntese da molécula de RNA pode ser agregada, de maneira análoga ao processo de duplicação do DNA, mas com a síntese de uma única fita, estando condicionada a ligação de um nucleotídeo U (Uracila, a ser confeccionado da mesma forma que os outros) ao A da molécula de DNA (A-U).

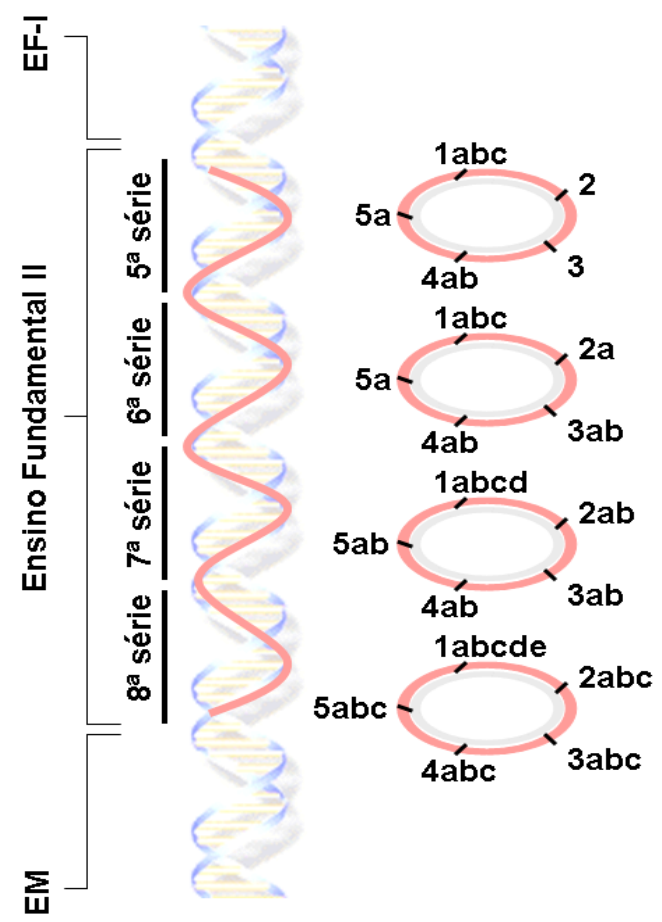

\section{LEGENDA}

1) Pareamento de nucleotídeos

a) Formato geométrico

b) Cor

c) Tamanho proporcional entre as figuras

d) Purinas e pirimidinas

e) Interações mediadas por estruturas

2) Forças de interação

a) Pontes de hidrogênio

b) Ligações covalentes

c) Ligação fosfo-diester

3) Formação de polímeros

a) Monômeros

b) Polímeros

c) Ligação por desidratação

4) Direcionamento das fitas

a) Fitas paralelas

b) Fitas anti-paralelas

c) Posição dos carbonos nas posições 3' e 5' da pentose

5) DNA como fonte da informação genética

a) Transferência de informações entre células mãe e filhas

b) Síntese de RNA

c) RNA como precursor da síntese de proteínas

Figura 3: Modelo em espiral de proposta de aprofundamento ao estudo da duplicação do DNA. A própria molécula de DNA serve de exemplo para demonstrar como o modelo de ensino em espiral funciona. Embora sejam mostrados apenas os conceitos aplicados no EF-II, é importante ter como referencial os conteúdos prévios aplicados em séries anteriores (EF-II, primeiro ciclo) e ter em mente que conceitos são fundamentais para que estes alunos carreguem tais conhecimentos adiante. Cada um dos círculos representa um giro de $360^{\circ}$ da espiral. Os números e as letras contidas em cada um dos círculos representam os conceitos e conteúdos que podem ser abordados em cada uma das séries que compõe o EF-II, e que se apresentam explicitados na legenda ao lado. Observe que a complexidade das informações é apresentada de acordo com a maturidade cognitiva dos alunos, mas que os conceitos básicos já podem ser vistos na quinta série ( $1^{a}$ série do EF-II). 


\section{2) Nutrição e respiração celular: 0 sangue como instrumento de distribuição de alimentos e oxigênio a todas as células do corpo}

\subsection{Materiais e métodos}

O total de alunos que compõe a sala deve ser dividido em cinco grupos com o respectivo número de alunos por grupo (Figura 4): 1) o grupo que representa os pulmões deverá ser formado por dois alunos, de preferência alunos com grande discrepância de tamanho, que seriam utilizados para representar o referencial de tamanho entre o pulmão direito (maior) e o esquerdo; 2) o grupo que representa as células/tecidos deve ser formado por quatro alunos, sendo dois responsáveis pela captação do gás oxigênio $\left(\mathrm{O}_{2}\right)$ e dois pela liberação do gás carbônico $\left(\mathrm{CO}_{2}\right)$ ao sangue; ambas as duplas terão funções mitocôndriais; 3) o grupo que representa o fígado deve ser formado por dois alunos, responsáveis pela degradação da hemoglobina e ruptura do anel porfirínico para a formação da bilirrubina a ser liberada no intestino junto com as fezes; 4) o grupo que representa a medula óssea será formado por quatro alunos, dos quais dois atuarão constantemente e dois em casos de necessidade orgânica, na produção de novas hemácias durante situações patológicas; 5) o grupo restante será composto por hemácias maduras e circulantes. Cada hemácia deverá ser composta por quatro alunos, de preferência duas meninas, representando as subunidades alfa, e dois meninos, representando as subunidades beta da hemoglobina (ver legenda Figura 4) $[6,7]$.

Balões previamente cheios de ar, na cor azul, representarão moléculas de $\mathrm{CO}_{2}$ liberadas pela célula durante o processo de respiração celular, ao passo que balões de cor vermelha representarão $\mathrm{O}_{2} \mathrm{O}_{2}$ captado pelos pulmões e incorporado na corrente sanguínea pelos alvéolos pulmonares, durante o processo de hematose [12]. Neste momento é possível fazer uma analogia anatomo-fisiológica com as figuras de corpo humano que apresentam em destaque vasos sangüíneos venosos (ricos em $\mathrm{CO}_{2}$ ) apresentados na coloração azul, para distinguir dos vasos arteriais (ricos em $\mathrm{O}_{2}$ ) na coloração vermelha, a clássica nomenclatura usada em livros de anatomia [13]. Papel crepom enrolado em forma de tira representa a membrana das hemácias, capaz de manter no seu interior a estrutura íntegra da hemoglobina $\left(\alpha_{2} \beta_{2}\right)$. A disposição das carteiras que compõem a sala de aula deve estar arrumada de maneira a formar um circuito de eventos propagados no seguinte sentido: pulmões (1) $\rightarrow$ sangue (2) $\rightarrow$ célula/tecidos (3) $\rightarrow$ pulmões (4) $\rightarrow$ pulmões (1).

Hemácias rompidas durante a circulação, ou seja, com ruptura do crepom durante a migração do sangue pelo caminho de carteiras deverão ser direcionadas ao fígado (5) onde será reciclada. A reciclagem constará de uma prévia separação das subunidades da hemoglobina, sucedida de uma clivagem do anel porfirínico. Este anel clivado será transformado em bilirrubina e sucessivamente eliminado pelas fezes. Parte das subunidades protéicas e o Ferro $\left(\mathrm{Fe}^{++}\right)$, proveniente do grupo heme, poderão ser destinados à medula óssea para uma síntese de novo de hemoglobina, a serem posteriormente recolocadas na corrente sanguínea. A regulação da síntese de novas hemoglobinas e atividade dos alunos extras que compõem a medula óssea será decorrente do aumento da lise de hemoglobinas sanguíneas. Hemoglobinas íntegras deverão transportar no máximo quatro moléculas de $\mathrm{O}_{2}$ ou $\mathrm{CO}_{2}$, uma para cada subunidade (aluno).

NOTA: $O$ transporte de $\mathrm{CO}_{2}$ pelas hemácias, no modelo proposto, teve a finalidade de deixar a metodologia mais dinâmica, entretendo os alunos por mais tempo durante a atividade. É importante destacar que embora $\mathrm{O} \mathrm{CO}_{2}$ possa ser transportado pela hemoglobina, como referenciado na figura, este processo corresponde a apenas $5 \%$ de todo $\mathrm{CO}_{2}$ transportado pelo sangue, já que a grande maioria deste gás é transportada após reagir com $\mathrm{H}_{2} \mathrm{O}$ por intermédio da enzima anidrase carbônica no interior da própria hemácia, resultando na formação de $\mathrm{H}_{2} \mathrm{CO}_{3}$ que, por ser instável, imediatamente se dissocia em $\mathrm{HCO}_{3}{ }^{-}+\mathrm{H}^{+}[6,7]$. 


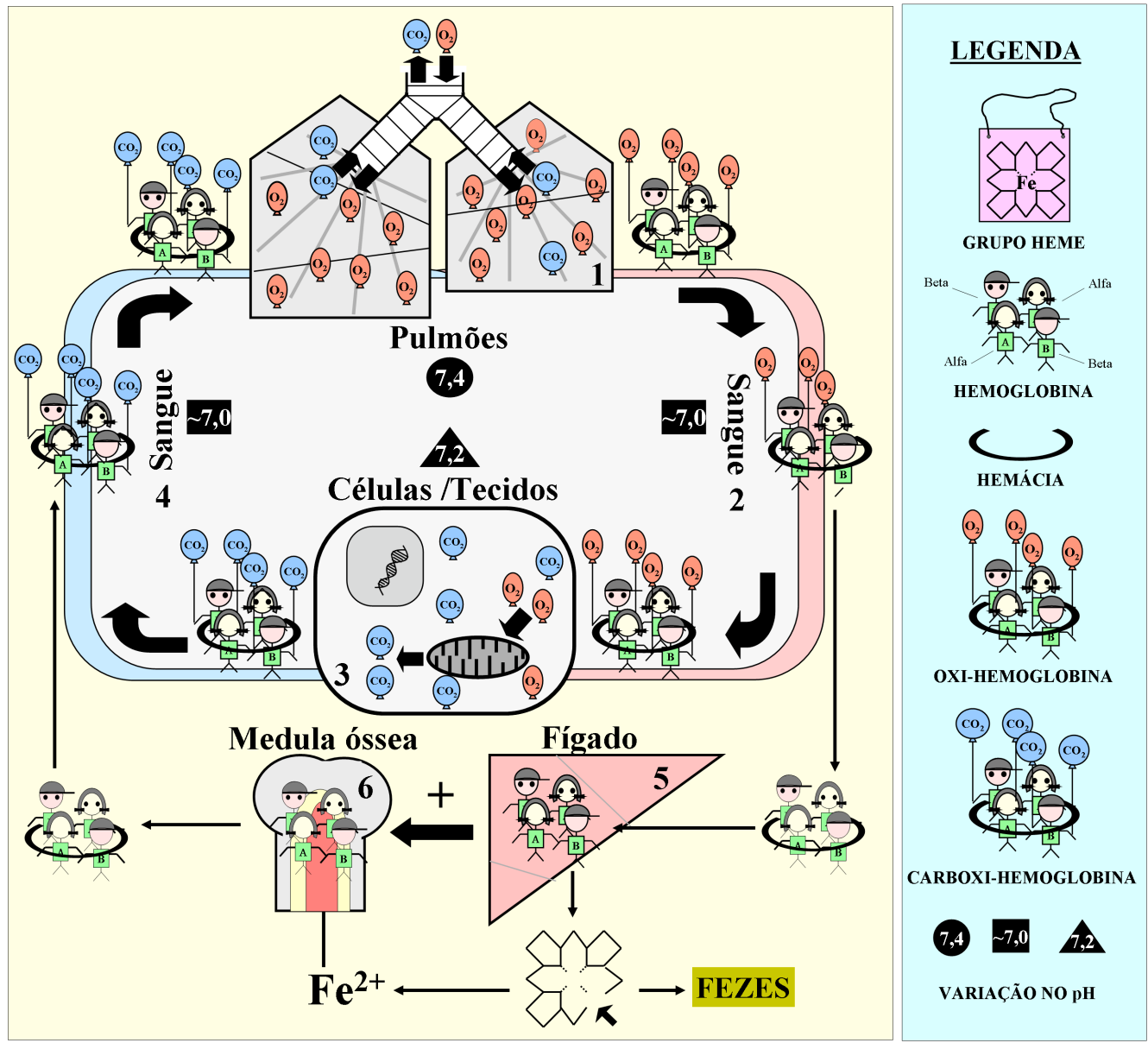

Figura 4: Transporte de gases pelo sangue mediado pela hemoglobina. A legenda à direita do esquema geral de transporte dos gases facilita a compreensão dos processos. No interior da hemácia (semicírculo preto) está a proteína chamada hemoglobina (conjunto de quatro crianças) formada basicamente por duas subunidades alfas (meninas) e duas subunidades betas (meninos). Cada uma destas subunidades apresenta no seu interior uma estrutura chamada de grupo heme, formada por quatro anéis porfirínicos que se ligam por intermédio de átomos de nitrogênio a um átomo de ferro, posicionado exatamente no centro deste complexo. Este átomo de ferro é que possui a particular funcionalidade de ligação ao oxigênio gasoso. Portanto, ao passar pelos pulmões cada subunidade de hemoglobina liga-se a uma molécula de $\mathrm{O}_{2}$, em uma pH médio de 7,4, tornando-se uma oxi-hemoglobina. Durante a migração para as células/tecidos começa a haver redução no $\mathrm{pH}$ sanguíneo, e em 7.2 há o desprendimento das moléculas de $\mathrm{O}_{2}$, agora aproveitados pelas células. A hemoglobina livre promove a captura das moléculas de $\mathrm{CO}_{2}$, subproduto da respiração celular, por afinidade ao $\mathrm{pH}$ reduzido, tornando-se uma carboxi-hemoglobina, que tenderá a migrar novamente aos pulmões, fechando o ciclo de trocas gasosas. É importante destacar que, embora o $\mathrm{CO}_{2}$ possa ser transportado pela hemoglobina, como referenciado na figura, este processo corresponde a apenas $5 \%$ de todo $\mathrm{CO}_{2}$ transportado pelo sangue, já que a grande maioria deste gás é transportada após reagir com $\mathrm{H}_{2} \mathrm{O}$ por intermédio da enzima anidrase carbônica no interior da própria hemácia, resultando na formação de $\mathrm{H}_{2} \mathrm{CO}_{3}$ que, por ser instável, imediatamente se dissocia em $\mathrm{HCO}_{3}{ }^{-}+\mathrm{H}^{+}[6,7]$. Caso ocorra ruptura da hemácia, representada por uma fita de papel crepom, durante a prática da atividade, a mesma deverá imediatamente ser direcionada ao fígado, onde sofrerá uma lise completa, proporcionando degradação da hemoglobina e ruptura do anel porfirínico que dará origem à bilirrubina a ser eliminada nas fezes. Parte do ferro do grupo heme mais os subprodutos da degradação de hemoglobina poderão ser utilizados pela medula óssea na síntese de novas hemácias, e esta resposta de síntese é diretamente regulada pela resposta de degradação pelo fígado. 


\subsection{Resultados obtidos e dificuldades iniciais de implementação}

Os resultados de aplicação desta metodologia em séries iniciais do EF-II não foram capazes de gerar resultados tão satisfatórios quanto os expressos na metodologia de duplicação da molécula de DNA (dados não mostrados). Entretanto, mesmo diante desta não satisfação, o conceito de que o transporte de $\mathrm{O}_{2}$ é feito exclusivamente pelas hemácias foi apreciado pela grande maioria dos alunos, assim como as diferenças entre sangue venoso e arterial puderam ser constatadas com facilidade pelas cores dos balões em associação às cores dos vasos sanguíneos apresentados em livros de anatomia humana [13].

As dificuldades e problemas mais freqüentes deparados durante a implementação da atividade estão listados a seguir:

- A hiperatividade dos alunos acarretou uma freqüente ruptura do papel crepom, o que impossibilitou que a dinâmica progredisse de forma tranqüila. Neste caso o grupo de alunos que compunha a medula óssea e o fígado foram os que mais trabalharam.

- Se a movimentação dos alunos (hemácias) ocorrer de forma brusca e desorientada, o crepom tenderá a se romper facilmente, e esta orientação deverá ser trabalhada com os alunos, reforçando o trabalho em equipe.

- A maior dificuldade observada se relaciona ao fato dos alunos entenderem o circuito como uma abordagem competitiva entre as hemácias circulantes, e isso não deve ocorrer. É interessante que o docente imponha um ritmo para que os alunos acompanhem e entendam que a oferta de oxigênio nos tecidos depende do fluxo circulatório, e que este fluxo é decorrente da atividade cardíaca e da ventilação pulmonar, que sofrem modificações rítmicas de acordo com a atividade física proposta.

- Embora o circuito tenha sido montado da forma como apresentado na Figura 4, alguns alunos nas séries iniciais se perderam. Setas de papel fixadas no chão evitarão a problemática, o que já foi comprovado em reaplicações da mesma metodologia.

Mesmo diante destas dificuldades supracitadas, o resultado mais apreciável desta aplicação se relacionou com a compreensão a respeito do verdadeiro significado do conceito respiração. Ficou muito claro para os alunos que a respiração consiste nas trocas gasosas que ocorrem exclusivamente nas células, quebrando um conhecimento quase que unânime da população em associar ventilação pulmonar (ato de inspirar e expirar gases) com a respiração celular propriamente dita. Este conceito bem assimilado é parte integrante de uma boa compreensão a respeito das organelas celulares envolvidas na manutenção da atividade celular, a serem estudadas mais adiante, em séries posteriores.

\section{CONSIDERAÇÕES FINAIS}

O intuito deste trabalho foi o de incentivar o ensino de ciências aplicadas, como bioquímica e biologia molecular, em séries iniciais do EF-II, não mediante a simples aplicações de conceitos, mas pelo prazer de se ensinar/aprender "brincando". Embora não seja uma tarefa fácil, como qualquer outra prática pedagógica, foi demonstrado com este trabalho que com um pouco de planejamento e uma visão de constante mudança na área educacional, um docente bem preparado pode influenciar severamente nas dinâmicas de aula e conseqüente apreciação de conhecimentos e conceitos técnicos por parte dos alunos [3], sem qualquer exigência formal, tão amplamente difundida no ensino Nacional. 
Diante dos resultados obtidos e das discussões já apresentadas anteriormente para cada modelo, são listados a seguir uma série de conclusões que tendem a sumarizar a importância destes trabalhos expressos por atividade lúdica no EF-II:

- Conhecer as variáveis que possam dificultar o ensino/aprendizagem é de extrema importância para a boa aceitação da metodologia. Fator este observado na melhoria dos conceitos satisfatórios durante as avaliações ou simplesmente pela expressão de frases que justificam a necessidade de mudanças metodológicas;

- Ter um conhecimento das diferentes inteligências que compõe o corpo discente facilita muito a escolha da melhor metodologia. Daí a importância de se conhecer os trabalhos de Howard Gardner a respeito das inteligências múltiplas [14];

- Embora o desenvolvimento de uma metodologia não resolva todas as problemáticas que circundam o processo ensino/aprendizagem, é notório que, se bem aplicada, facilita sua aceitação, e isto tende a favorecer a inter-relação entre professor-aluno, tão escassa no EF-II;

- As dificuldades impostas durante a aplicação da metodologia sempre servem de estímulo ao aprimoramento da mesma. Podemos atribuir como necessária e fundamental tais dificuldades para que a metodologia sofra constante alteração e aprimoramento;

- Uma mesma metodologia pode ser aplicada em diferentes séries, seguindo uma espiral de complexidade e se adaptando à maturidade cognitiva dos alunos. A esta espiral podem ser atribuídos práticas construtivistas que tenderão a enriquecer a discussão;

- Alunos empolgados com a disciplina e com o conteúdo passam a ser considerados importantes ferramentas de divulgação da informação técnica, já que o assunto passa a ser pauta de conversação entre membros da família, estimulando a escassa interação entre pais e filhos na difusão mútua de conhecimentos [15];

- Mais uma vez, fica comprovado que o lúdico favorece o processo de ensino/aprendizagem em qualquer nível escolar, grau hierárquico ou condição social, e, portanto, deve ser amplamente trabalhado $[5,16]$;

- O pânico, geralmente observado durantes as avaliações, foi reduzido, o que justifica a confiança pelo aprendizado dos conceitos mediantes aplicação da metodologia.

\section{AGRADECIMENTOS}

Em nome de Agsméia da Soledade Alves, agradeço ao colégio Gibran pela confiança no trabalho e no investimento em educação de qualidade, com constantes propostas de mudanças metodológicas de ensino. A todos os professores que, direta ou indiretamente, contribuíram para a discussão dos resultados, em especial para a Professora Carolina Irma Barreto Agulha pela importante ajuda na finalização deste trabalho. 


\section{REFERÊNCIAS BIBLIOGRÁFICAS}

[1] WATSON JD, CRICK FH (1953). Molecular structure of nucleic acids; a structure for deoxyribose nucleic acid. Nature, 171:737-738.

[2] YOKAICHIYA DK, GALEMBECK E, TORRES BB (2001). Expectativas e Fatores de Interesse por Ensino a Distância na área de Bioquímica: relatos de uma pesquisa pré e pós aplicação de uma disciplina de Bioquímica a Distância. RBEBBM, 2001.

[3] ABELL S, ROTH M (1995). Reflections On Fifth-Grade Life Science Lesson: Making Sense of Children's Understanding of Scientific Models. International Journal of Science Education, 17:59-74.

[4] PATON RC (1996). On an Apparently Simple Modelling Problem in Biology. International Journal of Science Education, 18:55-64.

[5] PEREIRA MP, PESTANA MEM (1991). Pupils' Representations of Models of Water. International Journal of Science Education, 13:313-319.

[6] VOET D, VOET JG (1995) Biochemistry, ed Second. New York: John Wiley \& Sons, Inc.

[7] MARZOCCO A, TORRES BB (1999) Bioquimica básica., ed 2. São Paulo: Guanabara Koogan.

[8] MESELSON M, STAHL FW (1958). The Replication of DNA in Escherichia coli. PNAS, 44:671-682.

[9] YOKAICHIYA DK, GALEMBECK E, TORRES BB (2004). O que os alunos de diferentes cursos procuram em disciplinas extracurriculares de Bioquímica? RBEBBM, 2004:artigo E.

[10] DOMINGUES CMAS, ALVARENGA AT (1997). Identidade e sexualidade no discurso adolescente / Identity and sexuality in adolescent discourse. Revista Brasileira de Crescimento e Desenvolvimento Humano, 7:32-68.

[11] VILLANI A, PACCA JLA (2001). Como avaliar um projeto de pesquisa em educação em ciências? Investigações em Ensino de Ciências, 6.

[12] GUYTON AC, HALL JC (1997) Tratado de fisiologia médica., ed 9. Rio de Janeiro: Guanabara Koogan.

[13] SOBOTTA J (1995) Atlas de Anatomia Humana., vol 1, ed 20. Rio de Janeiro.: Guanabara Koogan.

[14] GARDNER H (1995) Teoria das inteligências múltiplas. Porto Alegre: Artes Médicas.

[15] CARTER B, McGOLDRICK M (1995) As mudanças do ciclo de vida familiar. POA: Artes Médicas.

[16] BROUGÈRE G (1998). A criança e a cultura lúdica. Rev. Fac. Educ., 24:19-32. 